the outbreak of the present War, much research had been done by the Industrial Health Research Board, but the results were only partially utilized.

Research in industrial health is not merely making an inquiry after something untoward has happened; yet this conception of research is found at times even in government departments. Research calls for much time and patient work, and should be done by people trained in its techniques, Then its initial application should be taken as seriously as the initial research : the attitude of mind of the research worker who prides himself on indifference to the application is out of place in these health problems. Finally, the results should be expressed not only for the research worker but also in a form that can be understood by people who are not specialists. In 1939, the lamentable lack of knowledge on the subject of industrial health had the same results as in 1914, though with less excuse. Medical men had little if any knowledge of the industrial conditions they were expected to understand. This should not be attributed to them as a fault, but as throwing into relief a defect in their training. We know that the total working environment, the social environment and the personalities of the people in authority, quite apart from home conditions, all play a part in determining the sickness absence of workers. It is therefore a definite move in the right direction that the trustees of the Nuffield Foundation have offered the Universities of Durham, Glasgow and Manchester, centres of large industrial populations, the financial means for the furtherance of teaching and research. It is also noteworthy that co-operation is suggested between the new departments and other departments such as science and engineering, the relevant Ministries and trades union officials, and the Industrial Health Research Board. Nor should research be limited to those technically called workers, that is, workers at the bench, but should include all those engaged in work of any kind. The grants, which are to be spread over a period of ten years, have been allocated as follows: $£ 70,000$ to the University of Manchester for a chair of industrial health; and $£ 40,000$ each to the Universities of Durham and Glasgow, at the former for the establishment of a new department under a university reader, and at the latter for a Sub-Department of Industrial Health in the present Department of Social Medicine.

\section{Joint Council of Professional Scientists}

The Joint Council of Professional Scientists was established for the period of the national emergency, to voice the collective opinion of qualified men of science. It was originally a joint committee of representatives of the Royal Institute of Chemistry and of the Institute of Physics, which was set up for the purpose of fostering co-ordinated action in matters of common interest, and was developed by the co-option of a botanist, a geologist, a mathematician and a zoologist, there being no corresponding professional bodies to represent those branches of science. One of the representatives of the Royal Institute of Chemistry is a metallurgist of similar standing. The Council has now been working for two years. Among matters which have received, or are receiving, its attention are the proposal to urge the Government to establish a central scientific and technical board; the Ministry of Labour's announcernent regarding the minimum number of hours to be worked in laboratories and factories; the influence, on professional standards, of war-time university regulations governing the awaird of degrees ; the conditions of service of professional men of science in the Colonial service; and the national policy regarding research and development work.

In June 1943 the Council was responsible for the issue of a statement on "The Place of Scientists in the Community". The views expressed were generally supported and given wide publicity, in the lay and technical Press, not only in Great Britain but also abroad. The Council has specially concerned itself with the resettlement of professionally qualified men of science after the War and with the various proposals which have been put forward for the proper utilization of their services. At the invitation of the Ministry of Labour and National Service, representatives of the Council gave evidence before the Ministry's Committees on "Higher Appoint. ments" and on "The Further Education and Training of Demobilized Persons". Through the Joint Council, also, the Royal Institute of Chemistry and the Institute of Physics offered their continued co-operation with the Ministry in the resettlement period. The Council is also prepared to assist in the general resettlement of all who earn their living through their knowledge of any branch of natural science. Whether the Joint Council will continue in being when the national emergency no longer exists must depend on prevailing circumstances, and how far there may still be a need for professionally qualified men of science as such to voice their collective opinion on matters which concern the community in general, but especially themselves.

\section{Fuel and Power Advisory Council}

A Fuel and Power Advisory Council has been constituted as follows : Sir Ernest Simon (chairman), Mr. Geoffrey Crowther, Sir John Greenly, Dr. E. S. Grumell, Sir Harold Hartley, Prof. C. N. Hinshelwood, Prof. John Jewkes, Viscount Ridley, Sir Robert Robinson, Mr. Geoffrey Summers and Mr. R. N. Quirk (secretary). The terms of reference are: "To consider and advise upon questions, referred from time to time by the Minister to the Council, concerning the development and utilization of the fuel and power resources of the country in the national interest."

\section{Higher Technical Education in Great Britain}

IN a paper on "The Status of Higher Technical Education" published by the Association of Technical Institutions (Hon. Secretary, Loughborough College, Leics. 6d.), Dr. T. J. Drakeley, principal of the Northern Polytechnic, London, states that while on the Continent, "technical university studies are accorded the same status as university studies and both lead to the award of degrees, here, most of our best students, in fact most students have been discouraged from taking higher technical courses because of their apparent inferior nature"; consequently industry has received few trained men and has suffered the decline foretold by Lyon Playfair in 1852. Dr. Drakeley strenuously combats the foreign view (which is supported even by some British chemists) that "we do not possess the right temperament to maintain industrial progress", and claims that our ineffectiveness in the industrial field is due to our lack of appreciation of "the vast import. ance of technical training in the development of an industry - whereas we state that trade cannot be taught within a school, our foreign competitors realise that trade cannot be taught without a school". 